\title{
Assessing disease severity of rice blast under different rates of nitrogen fertilizer and planting system
}

\author{
Cipto Nugroho ${ }^{1}$, Didik Raharjo ${ }^{1}$, Muhammad Alwi Mustaha ${ }^{1}$, and Muhammad Asaad ${ }^{1,2}$ \\ ${ }^{1}$ Assessment Institute of Agricultural Technology of Southeast Sulawesi Province, J1. M. Yamin No. \\ 89, Puwatu, Kendari, Indonesia \\ ${ }^{2}$ Assessment Institute of Agricultural Technology South Sulawesi, Jl. Perintis Kemerdekaan Km. \\ 17.5, Sudiang, Makassar, Indonesia
}

\begin{abstract}
The study aimed to determine the effect of nitrogen rates and planting systems on the incidence and severity of rice blast under naturally infected rice plants and their relationship to rice yield performance. Recommended nitrogen rate for both direct seeding was $93.2 \mathrm{~kg} / \mathrm{ha}$. Treatments consisted of $75 \%$ recommended-N rate, $100 \%$ recommended-N rate, $150 \%$ recommended-N, and existing farmer's practice. Treatments were applied in a three-way splitted-N application at 14, 30, and 45 days after planting, respectively. The results indicate that rates of $\mathrm{N}$ fertilization affected disease incidence of the rice blast where the low-N application was generally lower than recommended-N rate, high- $\mathrm{N}$ rate, and farmer's practice, both on jajar legowo 2:1 and broadcasted direct seeding. This study revealed that recommended-N application, although has a higher disease incidence than low-N application, could tolerate yield loss due to rice blast by producing more productive tillers, number of grains per panicle, and reducing the number of unfilled grains. This study generally showed that jajar legowo 2:1 direct seeding gave lower disease incidence and severity to the rice blast than broadcasted direct seeding. The study suggested an appropriate recommended-N rate and jajar legowo 2:1 direct seeding (double row) was incorporated into the rice blast management strategies.
\end{abstract}

\section{Introduction}

Rice is a host of the pathogen anamorph Pyricularia oryzae (Cav.), the causal agent of blast disease in rice. This pathogen infects rice plants starting from nursery to maturity phase, causing leaf blasts, leaf collar blast, panicle neck blast, and panicle blast [1-3]. In general, the long period of wet leaves, high relative humidity, and temperatures between $17^{\circ} \mathrm{C}$ to $28^{\circ} \mathrm{C}$ support the development of blast disease in rice plants [4]. The tremendous adaptability causes the pathogen $\mathrm{M}$. oryzae to spread worldwide and become an epidemic in the tropics and sub-tropics [5].

Blast is an important rice disease and has threatened rice production worldwide, especially in rice-growing areas. Yield losses due to blast disease in Japan were around 60\%,

\footnotetext{
* Corresponding author: ciptonugroho@gmail.com
} 
Brazil 100\%, India 7.5\%, Korea 8\%, China 14\%, Philippines $67 \%$, Vietnam $60 \%$, Italy $24 \%$, and Iran $50 \%$ [6]. Whereas in Indonesia yield losses reaching up to $61 \%$ in the Ciherang variety [7]. In addition, [2] reported rice blast has spread widely in most rice-growing production in Indonesia, especially on Java. Although the pathogen was initially identified infecting upland rice varieties, recently the pathogen is commonly infecting lowland rice varieties. Furthermore, rice blast has also been identified in areas geographically located on islands other than Java, including Lampung, South Sumatra, Jambi, West Sumatra, Central Sulawesi, Southeast Sulawesi, and South Sulawesi, as well as in Central Kalimantan and South Kalimantan [7].

Several factors influence the incidence of rice blasts in Indonesia, such as; distribution and dominance of pathogen races in particular rice-growing areas which could reduce the effectiveness of resistant varieties, wide host range, namely; wheat, sorghum, and more than 40 species of Gramineae, availability of the host plants throughout the year, and unrecommended applications of nitrogen fertilization [1].

Nitrogen fertilization plays an important role in the severity and incidence of rice blast. Nitrogen deficiency in rice plants affects the expression of gene-associated pathogenicity of the M. oryzae [8-9]. The gene expression could induce the production of phytotoxic compounds leading to leaves senescence. Conversely, excess nitrogen fertilization significantly increases the incidence and severity of rice blast [10-12]. The excess of nitrogen fertilization increases the plant tissue susceptibility and rice canopy density which correlates with the increase of disease incidence and severity on the leaf and panicle blast [10-12]. In addition, plant canopy density directly increases the number of vulnerable plant tissues and performs a favorable environment for pathogen development [13]. Therefore, the density of plant canopies affects the interaction between pathogens and host plants.

Chemical control is widely used to suppress the incidence of rice blast. However, the incidence of rice blast is still widely distributed, especially in areas where farmers' fertilization practices are not following the recommendations and high population density of plants by the broadcasted direct seedling method. Therefore, information about the effect of Nitrogen fertilizer rates and plant population density on existing farmer cultivation practices is needed to effectively control rice blast. This study aimed to determine the effect of nitrogen fertilization rates and plant populations on the incidence and severity of rice blast in naturally infected rice plants in rainfed rice fields and their relationship to rice yield performance.

\section{Methodology}

The research was conducted in the second planting season of 2015, the dry season in July to December 2015 at Larowiu, Meluhu District, Konawe Regency, Southeast Sulawesi. The rice blast observed was a natural infection that occurred in the field. The study site was chosen based on the history of rice blast incidence in the last two planting seasons. Based on farmer and field reports, it was found that the study site was an endemic area of the rice blast incidence which occurred during the planting season of July - December 2014 (dry season) and January - June 2015 (rainy season) in Mekongga varieties.

The experiment was arranged a factorial design with two factors and four replications. The first factor was the rice planting system of direct seeding jajar legowo 2:1 (A) and broadcasted direct seeding (B); and the second factor was Nitrogen fertilizer rates, i.e. $75 \%$ Nitrogen rate, $100 \%$ Nitrogen rate, and $150 \%$ Nitrogen rate of recommendation, as well as Nitrogen rate which was commonly used by the farmer. 


\subsection{Land preparation of experimental field}

Rice field was prepared through totally puddled soil which involves (1) plowing to dig up, mix, and overturn the soil; (2) harrowing to break the soil clods into smaller masses and incorporate plant residue, and (3) leveling the field. Land preparation took three weeks before planting. After leveling the field, the $30 \mathrm{~cm}$ wide dike was made as a border among the experimental plots. The size of an experimental plot was $10 \times 10 \mathrm{~m}$. After the plots were formed and the dikes were hardened, the plots were flooded and keep it submerged for at least two weeks. The plots were drained naturally until ready to be planted.

\subsection{Seedling preparation and planting}

The study used the Mekongga variety based on susceptibility to rice blast during the last two growing seasons at the study site. The number of seeds used in four plots of direct seedling jajar legowo 2:1 was $2.4 \mathrm{~kg}$, while broadcasted direct seedling (existing farmers) used $1 \mathrm{~kg}$ of seed for each experimental plot. Seed selection was carried out by soaking the seeds in a $\mathrm{NaCl}$ solution of 20 grams/liter of water. Floating seeds were discarded while sinking seeds were used for planting. Selected seeds were rinsed with tap water to remove $\mathrm{NaCl}$. The seeds were then soaked for 24 hours and drained 24 hours before planting.

Direct seedling jajar legowo 2:1 was carried out by using direct-seeded equipment made of a 5-inch PVC pipe with a length of $180 \mathrm{~cm}$. The distance between two rows of plants was $20 \mathrm{~cm}$ and the distance between double rows of plants was $40 \mathrm{~cm}$. The distance between holes in the pipe circumference was $4.36 \mathrm{~cm}$, thus there were 9 holes in one row. The hole was made by using an electric drill with drill bit number 13. At the end of the pipe, wheels with a diameter of 17 inches were installed. The wheel serves to rotate the pipe and the seeds then pour on the ground with a predetermined distance when the equipment was pulled.

Broadcasted direct seedling (farmer's practice) was carried out by spreading seeds directly by hand on the ground. For every $\pm 4 \mathrm{~m}$ distance, $\pm 30 \mathrm{~cm}$ lane was made to facilitate plant maintenance. The lanes were made by pulling a sack of sand weighing approximately $5 \mathrm{~kg}$.

Plant maintenance includes the management of weeds and pests. Pre-emergent herbicide was applied at 7 DAP. Post-emergent herbicide was applied based on observations of weed density per square meter at 14 DAP. Post-emergent herbicide was applied if weed densities were more than $50 \%$ per square meter. Weeds that survive after 30 DAP were controlled manually. Insecticides were used to control pests based on the type and incidence of pests.

\subsection{Determination of Nitrogen fertilizer rates}

Nitrogen fertilization rates were determined based on a paddy soil test kit released by the Indonesian Agency for Agricultural Research and Development (IAARD). Based on the analysis, fertilizer recommendations on the study area were $93.2 \mathrm{~kg} / \mathrm{ha}$ Nitrogen, $100 \mathrm{~kg} / \mathrm{ha}$ Phosphorus, and $50 \mathrm{~kg} / \mathrm{ha}$ of Potassium. Therefore, there were three doses of Nitrogen fertilizer treatment, namely $75 \%$ of recommendations or $69.9 \mathrm{~kg} /$ ha of Nitrogen, $100 \%$ of recommendations or $93.2 \mathrm{~kg} / \mathrm{ha}$ of Nitrogen, and $150 \%$ of recommendations or $139.8 \mathrm{~kg} / \mathrm{ha}$ of Nitrogen. Phosphorus and potassium were applied according to the paddy soil test kit recommendation.

Fertilizers were splitted into three applications. The first fertilization was at 14 days after planting (DAP), the second fertilization was at $30 \mathrm{DAP}$, and the third fertilization was at 45 DAP. Fertilizer was applied by converting the composition of Nitrogen, Phosphorus, and Potassium into NPK Phonska complete fertilizer containing 15\% Nitrogen, 15\% Phosphorus, and $15 \%$ Potassium. Phosphorus was also converted into SP-36 fertilizer containing 
Phosphorus $36 \%$. In addition, Nitrogen was also converted into Urea fertilizer containing Nitrogen 46\%. NPK Phonska and SP-36 were produced by Petrokimia Gresik Co., while Urea was produced by Pupuk Indonesia Group Co. Phosphorus, Potassium, and a portion of Nitrogen were applied entirely in NPK Phonska and SP-36 at first fertilization, while the other part of Nitrogen was applied in Urea at second and third fertilization (Table 4). Furthermore, fertilization on the existing farmer treatment was applied in $200 \mathrm{~kg}$ NPK Phonska and $150 \mathrm{~kg}$ Urea. One hundred kilograms of Urea was applied at the first fertilization. Then at the second fertilization, $150 \mathrm{~kg}$ of NPK Phonska was applied. In addition, $50 \mathrm{~kg}$ of Urea and $50 \mathrm{~kg}$ of NPK Phonska were applied at the third fertilization.

\subsection{Disease measurement and statistical analysis}

Disease severity was observed for 10 hills sampled systematically on each trial plot. Hills were marked with a bamboo stick. Leaf blast infection was observed at 45 DAP, while panicle blast infection was observed at 75 DAP. The leaves observed were the top five leaves of the hill, while the panicle blast was observed for five infected panicles in each hill. The scale of disease severity of leaf blasts was measured according to the dominant type of infection using $0-9$ standard scoring (Table 1).

Table 1. Standard scoring system for leaf blast based on the dominant type of infection (IRRI, 2014)

\begin{tabular}{cll}
\hline $\begin{array}{c}\text { Lesion type } \\
\text { (score) }\end{array}$ & \multicolumn{1}{c}{ Description } & \multicolumn{1}{c}{ Reaction } \\
\hline 0 & $:$ No lesion observed & $\begin{array}{l}\text { Resistant (R) } \\
\text { Resistant (R) }\end{array}$ \\
1 & $: \begin{array}{l}\text { Small brown specks of pinpoint size or larger brown } \\
\text { specks without sporulating center }\end{array}$ & Resistant (R) \\
3 & $: \begin{array}{l}\text { Small, roundish to slightly elongated necrotic } \\
\text { sporulating spots, about 1-2 mm in diameter with a } \\
\text { distinct brown margin or yellow hallow }\end{array}$ & \\
5 & $: \begin{array}{l}\text { A narrow or slightly elliptical lesion, 1-2 mm in breadth, } \\
\text { more than 3 mm long with a brown margin }\end{array}$ & $\begin{array}{l}\text { Moderately } \\
\text { Resistant (MR) } \\
\text { Susceptible (S) }\end{array}$ \\
7 & $: \begin{array}{l}\text { A broad spindle-shaped lesion with a yellow, brown, or } \\
\text { purple margin }\end{array}$ & Susceptible (S) \\
\hline & $: \begin{array}{l}\text { Rapid coalescing small, whitish, grayish, or bluish } \\
\text { lesions without distinct margins }\end{array}$ & \\
\hline
\end{tabular}

While the disease severity of panicle blast was measured based on the symptoms using $0-9$ standard scoring (Table 2).

Table 2. Standard scoring system for panicle blast based on the appearance of the symptoms (IRRI, 2014)

\begin{tabular}{|c|c|c|}
\hline $\begin{array}{l}\text { Lesion type } \\
\text { (score) }\end{array}$ & Description & Reaction \\
\hline 0 & : No visible lesion or observed lesions on only a few pedicels & Resistant (R) \\
\hline 1 & : Lesions on several pedicels or secondary branches & Resistant (R) \\
\hline 3 & $\begin{array}{l}\text { Lesions on a few primary branches or the middle part of the } \\
\text { panicle axis }\end{array}$ & Resistant (R) \\
\hline 5 & $\begin{array}{l}\text { Lesions partially around the base (node) or the uppermost } \\
\text { internode or the lower part of the panicle axis near the base }\end{array}$ & $\begin{array}{l}\text { Moderately } \\
\text { Resistant (MR) }\end{array}$ \\
\hline 7 & $\begin{array}{l}\text { Lesions completely around panicles base or uppermost } \\
\text { internode or panicle axis near the base with more than } 30 \% \\
\text { of filled grain }\end{array}$ & Susceptible (S) \\
\hline 9 & $\begin{array}{l}\text { Lesions completely near panicle base or uppermost internode } \\
\text { or the panicle axis near the base with less than } 30 \% \text { of filled } \\
\text { grain }\end{array}$ & Susceptible (S) \\
\hline
\end{tabular}


Rice blast incidence was observed visually on infected panicles in each experimental plot using $0-9$ standard scoring (Table 3).

Table 3. Standard scoring system for rice blast incidence based on infected panicle observation (IRRI, 2014)

\begin{tabular}{cll}
\hline $\begin{array}{c}\text { Disease incidence } \\
\text { (score) }\end{array}$ & \multicolumn{1}{c}{ Description } & \multicolumn{1}{c}{ Reaction } \\
\hline 0 & $:$ no disease observed & Resistant (R) \\
1 & $:$ less than 5\% & Resistant (R) \\
3 & $: 5-10 \%$ & Resistant (R) \\
5 & $: 11-25 \%$ & Moderately Resistant (MR) \\
7 & $:$ 26 $-50 \%$ & Susceptible (S) \\
9 & $:$ more than 50\% & Susceptible (S) \\
\hline
\end{tabular}

$\overline{\text { Data were submitted to Analysis of Variance (ANOVA) using statistical tool SPSS software version } 22}$ and means were compared by Duncan's Multiple Range Test (DMRT) at $P 0.05$.

\section{Results and discussion}

\subsection{Effect of Nitrogen fertilization}

Table 4. Nitrogen fertilizer rates and disease severity of rice blast in jajar legowo 2:1 direct seeding and broadcasted direct seeding in Konawe Regency, Southeast Sulawesi, dry season 2015.

\begin{tabular}{|c|c|c|c|c|c|}
\hline \multirow{2}{*}{$\begin{array}{c}\mathbf{N} \\
\text { applica- } \\
\text { tion }\end{array}$} & \multirow{2}{*}{$\begin{array}{c}\text { Splitted } \\
\text { N rates } \\
\text { (kg/ha) }\end{array}$} & \multicolumn{2}{|c|}{$\begin{array}{l}\text { Disease severity of } \\
\text { leaf blast }^{(b)} 45 \text { DAP }\end{array}$} & \multicolumn{2}{|c|}{$\begin{array}{c}\text { Disease severity of panicle } \\
\text { blast }^{(\mathbf{b})} 75 \text { DAP }\end{array}$} \\
\hline & & $\begin{array}{c}\text { Jajar legowo } \\
2: 1\end{array}$ & $\begin{array}{l}\text { Broad- } \\
\text { casted }\end{array}$ & $\begin{array}{c}\text { Jajar legowo } \\
2: 1\end{array}$ & $\begin{array}{l}\text { Broad- } \\
\text { casted }\end{array}$ \\
\hline $75 \%$ & $50-10-9.9$ & $12.22 \%$ & $45.33 \%$ & $17.25 \%$ & $42.43 \%$ \\
\hline $100 \%(\mathrm{c})$ & $50-21.6-21.6$ & $14.12 \%$ & $19.23 \%$ & $28.15 \%$ & $48.23 \%$ \\
\hline $150 \%$ & $50-44.9-44.9$ & $22.23 \%$ & $52.46 \%$ & $31.26 \%$ & $49.15 \%$ \\
\hline $\begin{array}{l}\text { Farmer's } \\
\text { practice }\end{array}$ & $46-22.5-30.5$ & $15.33 \%$ & $17.16 \%$ & $28.26 \%$ & $44.45 \%$ \\
\hline
\end{tabular}

${ }^{a}$ Splitted-N rates designate the Nitrogen given in three applications, namely first fertilization at 14 days after planting (DAP), second fertilization at 30 DAP, and third fertilization at 45 DAP. Phosphorus, Potassium, and a portion of Nitrogen were given entirely in NPK Phonska and SP-36 fertilizers at first fertilization, while some $\mathrm{N}$ was given in Urea at the second and third fertilization. The existing farmer's fertilization is as follows; first fertilization was given $100 \mathrm{~kg}$ of Urea, second fertilization was given $150 \mathrm{~kg}$ of NPK Phonska, third fertilization was given $50 \mathrm{~kg}$ of Urea and $50 \mathrm{~kg}$ of NPK Phonska.

${ }^{\mathrm{b}}$ Relative field resistant of the rice blast: $0-3=$ resistant; $5=$ moderately resitant; $7-9=$ susceptible.

${ }^{\mathrm{c}}$ Recommended Nitrogen based on soil test kit released by IAARD

\subsection{Symptoms of rice blast}

The study revealed that the effect of Nitrogen on leaf blast severity was similar among the treatments of jajar legowo 2:1 direct seeding which is ranged from $12.22 \%$ to $22.23 \%$ and considered moderately symptom. The symptoms showed a slightly elliptical lesion with 1-2 $\mathrm{mm}$ diameter, more than $3 \mathrm{~mm}$ length, and brown margin. However, in broadcasted direct seeding, the symptoms of the leaf blast showed different severity among the Nitrogen rate treatments, where $75 \%$ and $150 \%$ of $\mathrm{N}$ rate showed highly severe symptoms ( $>25 \%$ disease severity) while the other treatment showed moderate symptoms (11\%-25\% severity). In highly severe symptoms, the lesions completely appeared a broad spindle-shaped lesion with a yellow, brown, or purple margin. 
Furthermore, the severity of the panicle blast showed different symptoms among the Nitrogen rate treatments in jajar legowo 2:1 direct seeding, where $75 \%$ of $\mathrm{N}$ rate showed moderate symptoms (11\%-25\% disease severity) while the other treatment showed highly severe symptoms ( $>25 \%$ severity). The symptom showed lesions completely around the panicle base or uppermost internode or panicle axis near the base with more than $30 \%$ of the filled grain. Otherwise, there were no differences in severity of the panicle blast on broadcasted direct seeding. The panicles were highly severe ( $>25 \%$ disease severity) where the symptoms showed lesions completely around the panicle base with more than $30 \%$ of filled grain or susceptible reaction to panicle blast.

Table 5. Nitrogen fertilizer rates and disease incidence of rice blast in jajar legowo 2:1 direct seeding and broadcasted direct seeding 75 days after planting in Konawe Regency, Southeast Sulawesi, dry season 2015.

\begin{tabular}{lccc}
\hline \multirow{2}{*}{$\begin{array}{c}\mathbf{N} \\
\text { application }\end{array}$} & $\begin{array}{c}\text { Splitted } \\
\mathbf{N} \text { rates }^{\text {(a) }} \\
\mathbf{( k g / h a )}\end{array}$ & $\begin{array}{c}\text { Jajar legowo } \\
\mathbf{2 : 1}\end{array}$ & Broadcasted \\
\cline { 3 - 4 } & $50-10-9.9$ & $45.63 \mathrm{a}$ & $54.67 \mathrm{a}$ \\
$100 \%$ & $50-21.6-21.6$ & $52.63 \mathrm{~b}$ & $58.82 \mathrm{~b}$ \\
$150 \%$ & $50-44.9-44.9$ & $50.93 \mathrm{~b}$ & $57.21 \mathrm{~b}$ \\
Farmer's & $46-22.5-30.5$ & $49.45 \mathrm{~b}$ & $56.25 \mathrm{~b}$
\end{tabular}

practice

Splitted-N rates designate the Nitrogen given in three applications, namely first fertilization at 14 days after planting (DAP), second fertilization at 30 DAP, and third fertilization at 45 DAP. Phosphorus, Potassium, and a portion of Nitrogen were given entirely in NPK Phonska and SP-36 fertilizers at first fertilization, while some $\mathrm{N}$ was given in Urea at the second and third fertilization. The existing farmer's fertilization is as follows; first fertilization was given $100 \mathrm{~kg}$ of Urea, second fertilization was given $150 \mathrm{~kg}$ of NPK Phonska, third fertilization was given $50 \mathrm{~kg}$ of Urea and $50 \mathrm{~kg}$ of NPK Phonska.

* Means in the same column followed by the different letters differ significantly under DMRT $(\alpha \leq 5 \%)$

The average disease incidence was considerably higher on broadcasted direct seeding than jajar legowo 2:1 direct seeding $(p=0.05)$. Otherwise, the effect of the $\mathrm{N}$ treatments on disease incidence was similar on broadcasted direct seeding and jajar legowo 2:1 direct seeding. The differences in disease incidence were attributed to different rates of $\mathrm{N}$ observed on broadcasted direct seeding and jajar legowo 2:1 direct seeding. The application of $75 \% \mathrm{~N}$ significantly has the lowest disease incidence of rice blast, both on broadcasted direct seeding and jajar legowo 2:1 direct seeding. On the other hand, there were no differences among the $100 \%, 150 \%$, and farmer's practice of $\mathrm{N}$ application on broadcasted direct seeding and jajar legowo 2:1 direct seeding.

This study illustrated two important points regarding the rice blast under natural infection in Southeast Sulawesi, Indonesia. Firstly, rates of $\mathrm{N}$ fertilization affected disease incidence of the rice blast under natural infection where the low-N application was generally lower than recommended-N rate, high-N rate, and farmer's practice, both on jajar legowo 2:1 and broadcasted direct seeding. However, the application of the $\mathrm{N}$ rate reflects in yield production. Development of rice blast was determined by $\mathrm{N}$ application where disease incidence on the high-N application was generally higher than normal-N application on the susceptible cultivar [11-12]. Nitrogen rates stimulate tillering and formation of leaves which is causing canopy shading where it makes a favorable environment for disease development and reduces productivity [14-15]. In addition, a high level of $\mathrm{N}$ application could decrease $\mathrm{Si}$ content which affects disease tolerance of the plant [16].

Secondly, plant density plays important role in disease incidence and severity of the rice blast under natural infection. This study generally showed that jajar legowo 2:1 direct seeding gave lower disease incidence and severity to the rice blast than broadcasted direct seeding. In Indonesia, the jajar legowo planting system is widely practiced by farmers. There are 
numerous types of jajar legowo, namely 2:1, 4:1, 6:1, and 8:1 planting patterns [17]. In a place where labor is limited and high labor cost, the jajar legowo planting system is modified to jajar legowo direct seeding. Jajar legowo is a rice planting pattern by creating open rows after regular rows. This planting pattern makes all rice hills recognized as edge rows. Moreover, the edge rows would get more sunlight and open rows makes better air circulation. One of the most important things in creating this condition is the modification of microclimate under the plant canopy to suppress plant pathogen development [18].

One of the major challenges in direct seeding rice is the incidence of the rice blast [19]. The rice blast development is influenced by main climatic factors, such as temperature and humidity [20]. Canopy architecture, radiation, air, and soil temperature, and wind are the main factors determining the moisture profile under the canopy which influence disease development specifically [13]. In addition, plant spacing and gaps under the canopy increase ventilation to influence canopy wetness. Furthermore, the development of plant-pathogen is determined by the duration of surface wetness, percolation of rain through the canopy, and the level of relative humidity. White mold disease, caused by Sclerotinia sclerotiorum, in bean, the dense canopies offer extended periods of surface wetness and favorable condition for disease development [21]. Moreover, plant spacing influenced rice blast development where increasing plant spacing caused an increase in leaf area and midday canopy air temperature, and decrease in mean tip angle, light interception, dew amount, leaf wetness duration, and midday canopy relative humidity [13]. In addition, increased spacing among hills provided a significant dilution effect which contributed to the high level of disease control [22]. Therefore, inoculum dilution plays important role in reducing disease infection by the increasing distance between plants.

\subsection{Effect of Nitrogen fertilization on rice yield}

Table 6. Nitrogen fertilizer rates, agronomic traits of rice, and yield of jajar legowo 2:1 direct seeding under natural infections of Pyricularia oryzae Cav. in Konawe Regency, Southeast Sulawesi, dry season 2015.

\begin{tabular}{lccccccc}
\hline $\begin{array}{c}\mathbf{N} \\
\text { applica- } \\
\text { tion }\end{array}$ & $\begin{array}{c}\text { Splitted } \\
\mathbf{N} \text { rates }^{(\mathbf{a})} \\
\mathbf{( k g / h a )}\end{array}$ & $\begin{array}{c}\text { Plant } \\
\text { height } \\
\mathbf{( c m )}\end{array}$ & $\begin{array}{c}\text { Pro- } \\
\text { ductive } \\
\text { tillers }\end{array}$ & $\begin{array}{c}\text { Grains } \\
\text { per } \\
\text { panicle }\end{array}$ & $\begin{array}{c}\text { Unfilled } \\
\text { grains } \\
\mathbf{( \% )}\end{array}$ & $\begin{array}{c}\mathbf{1 0 0 0 -} \\
\text { grain } \\
\text { weight } \\
\mathbf{( g )}\end{array}$ & $\begin{array}{c}\text { Yield } \\
(\mathbf{t} / \mathbf{h a})\end{array}$ \\
\hline $75 \%$ & $50-10-9.9$ & $71.75 \mathrm{a}$ & $12.75 \mathrm{~b}$ & $92.00 \mathrm{c}$ & $16.50 \mathrm{c}$ & $23.00 \mathrm{~b}$ & $3.00 \mathrm{~b}$ \\
$100 \%$ & $50-21.6-21.6$ & $71.50 \mathrm{a}$ & $13.50 \mathrm{a}$ & $97.25 \mathrm{a}$ & $18.50 \mathrm{~b}$ & $23.25 \mathrm{a}$ & $4.00 \mathrm{a}$ \\
$150 \%$ & $50-44.9-44.9$ & $69.25 \mathrm{a}$ & $12.50 \mathrm{~b}$ & $97.75 \mathrm{a}$ & $21.50 \mathrm{a}$ & $22.50 \mathrm{c}$ & $2.25 \mathrm{c}$ \\
$\begin{array}{l}\text { Farmer's } \\
\text { practice }\end{array}$ & $46-22.5-30.5$ & $71.00 \mathrm{a}$ & $12.70 \mathrm{~b}$ & $94.75 \mathrm{~b}$ & $19.75 \mathrm{a}$ & $22.50 \mathrm{c}$ & $3.00 \mathrm{~b}$ \\
\hline
\end{tabular}

Splitted-N rates designate the Nitrogen given in three applications, namely first fertilization at 14 days after planting (DAP), second fertilization at 30 DAP, and third fertilization at 45 DAP. Phosphorus, Potassium, and a portion of Nitrogen were given entirely in NPK Phonska and SP-36 fertilizers at first fertilization, while some $\mathrm{N}$ was given in Urea at the second and third fertilization. The existing farmer's fertilization is as follows; first fertilization was given $100 \mathrm{~kg}$ of Urea, second fertilization was given $150 \mathrm{~kg}$ of NPK Phonska, third fertilization was given $50 \mathrm{~kg}$ of Urea and $50 \mathrm{~kg}$ of NPK Phonska.

* Means in the same column followed by the different letters differ significantly under DMRT $(\alpha \leq 5 \%)$

Based on tables 6 and 7, jajar legowo 2:1 direct seeding considerably has better performance than broadcasted direct seeding under natural infection of the rice blast. The jajar legowo 2:1 direct seeding has the higher average of plant height, number of productive tillers, number of grain per panicle, and 1000 grain weight, but a lower number of unfilled grain per panicle compared with broadcasted direct seeding. However, different rate of $\mathrm{N}$ treatments significantly affects the number of productive tillers, grain per panicle, unfilled grain, and 
1000 grain weight on both jajar legowo 2:1 and broadcasted direct seeding, except plant height which insignificant different among the $\mathrm{N}$ treatments on both jajar legowo 2:1 and broadcasted direct seeding. An insignificant difference in plant height among the $\mathrm{N}$ treatments was caused by the reaction of the rice plant to disease pressure.

This study revealed that disease incidence and severity affected yield production of rice by $r=-0.441(\alpha=0.05)$ and $r=-0.498(\alpha=0.01)$ respectively. However, recommended $\mathrm{N}$ application could tolerate environmental stresses due to invasion of pathogens. Under susceptible reaction to rice blast on natural infection, $100 \% \mathrm{~N}$ application gave the highest yield of 4.00 tons/ha on jajar legowo 2:1 direct seeding, significantly different among other $\mathrm{N}$ treatments. This rice production was contributed by the high number of productive tillers (13.5 tillers), the high number of grains per panicle (97.25 grains), and the weight of 1000 grains $(23.25 \mathrm{~g})$. In addition, $100 \% \mathrm{~N}$ application has a relatively low percentage of unfilled grains per panicle $(18.5 \%)$.

Similar to jajar legowo 2:1 direct seeding, 100\% N application gave the highest yield of 3.00 tons/ha on broadcasted direct seeding, significantly different among other $\mathrm{N}$ treatments. Even though there were insignificant differences of 1000 grains weight among $\mathrm{N}$ treatments, the $100 \% \mathrm{~N}$ application significantly gave the highest productive tillers, the number of grains per panicle, and the lowest percentage of unfilled grains. This study showed that under natural infection of the rice blast, the recommended $\mathrm{N}$ application could tolerate by compensating the rice yield production.

Interestingly, this study revealed that recommended-N application, even though has a higher disease incidence than low-N application, could tolerate yield loss due to rice blast by producing more productive tillers, number of grains per panicle, and reducing the number of unfilled grains. The number of stalks and productive tillers is a response to nitrogen fertilization which is related to the nitrogen availability in the plant [14]. However, increasing the $\mathrm{N}$ fertilization level from the recommended $\mathrm{N}$ application could reduce the grain yield. The incidence in panicle blast was highly correlated with the incidence of leaf blast and was reported directly affect to yield loss and that leaf and collar infection affect yield less [23]. The reduction in productivity probably resulted from the high intensity of the disease which affected the grain filling stage were then in turn affected the amount of unfilled grain and the reduction of grain weight. The previous study reported that an increase in disease severity can reduce the number of tillers and panicles, the number of grains per panicle, and grain weight which influence grain yield [24-25].

Table 7. Nitrogen fertilizer rates, agronomic traits of rice, and yield of broadcasted direct seeding under natural infections of Pyricularia oryzae Cav. in Konawe Regency, Southeast Sulawesi, dry season 2015.

\begin{tabular}{lccccccc}
\hline $\begin{array}{c}\mathbf{N} \\
\text { applica- } \\
\text { tion }\end{array}$ & $\begin{array}{c}\text { Splitted } \\
\text { N rates } \\
(\mathbf{k g} / \mathbf{h a})\end{array}$ & $\begin{array}{c}\text { Plant } \\
\text { height } \\
\mathbf{( c m )}\end{array}$ & $\begin{array}{c}\text { Product } \\
\text { ive } \\
\text { tillers }\end{array}$ & $\begin{array}{c}\text { Grains } \\
\text { per } \\
\text { panicle }\end{array}$ & $\begin{array}{c}\text { Unfilled } \\
\text { grains } \\
(\mathbf{\%})\end{array}$ & $\begin{array}{c}\mathbf{1 0 0 0 -} \\
\text { grain } \\
\text { weight } \\
\mathbf{( g )}\end{array}$ & $\begin{array}{c}\text { Yield } \\
(\mathbf{t} / \mathbf{h a})\end{array}$ \\
\hline $75 \%$ & $50-10-9.9$ & $67,50 \mathrm{a}$ & $7.50 \mathrm{~b}$ & $88.75 \mathrm{c}$ & $19.00 \mathrm{~b}$ & $22.25 \mathrm{a}$ & $2.25 \mathrm{~b}$ \\
$100 \%$ & $50-21.6-21.6$ & $66,75 \mathrm{a}$ & $14.00 \mathrm{a}$ & $98.00 \mathrm{a}$ & $17.25 \mathrm{c}$ & $21.75 \mathrm{a}$ & $3.00 \mathrm{a}$ \\
$150 \%$ & $50-44.9-44.9$ & $65,50 \mathrm{a}$ & $8.50 \mathrm{~b}$ & $92.25 \mathrm{~b}$ & $17.25 \mathrm{c}$ & $22.00 \mathrm{a}$ & $2.00 \mathrm{c}$ \\
$\begin{array}{l}\text { Farmer's } \\
\text { practice }\end{array}$ & $46-22.5-30.5$ & $64,75 \mathrm{a}$ & $6.50 \mathrm{c}$ & $93.50 \mathrm{~b}$ & $22.25 \mathrm{a}$ & $23.25 \mathrm{a}$ & $2.75 \mathrm{~b}$ \\
\hline
\end{tabular}

Splitted-N rates designate the Nitrogen given in three applications, namely first fertilization at 14 days after planting (DAP), second fertilization at 30 DAP, and third fertilization at 45 DAP. Phosphorus, Potassium, and a portion of Nitrogen were given entirely in NPK Phonska and SP-36 fertilizers at first fertilization, while some $\mathrm{N}$ was given in Urea at the second and third fertilization. The existing farmer's fertilization is as follows; first fertilization was given $100 \mathrm{~kg}$ of Urea, second fertilization was given $150 \mathrm{~kg}$ of NPK Phonska, third fertilization was given $50 \mathrm{~kg}$ of Urea and $50 \mathrm{~kg}$ of NPK Phonska.

* Means in the same column followed by the different letters differ significantly under DMRT $(\alpha \leq 5 \%)$ 
Lastly, integrated rice blast management has been suggested to prevent yield loss at the farmer's level. In Indonesia, recommended rice blast management strategies incorporate cultural practice (i.e., plant rotation, nutrient management, water management, and seed-free pathogens), the use of resistant varieties, and fungicides [26]. These strategies, indeed, contribute to reducing rice blast development. However, their implementation is very difficult to be applied to the farmer's practice. The lack of management strategies, particularly $\mathrm{N}$ fertilization has been found to affect rice blast development. This study suggested recommended $\mathrm{N}$ fertilization according to the soil test kit, released by IAARD, could tolerate disease suppression due to rice blast. Recommended-N fertilization has reached the highest grain yield compared with low-N, high-N, and farmer's practice fertilization. Furthermore, the planting system is suggested to be part of the rice blast management strategies since jajar legowo 2:1 direct seeding reduced disease incidence and severity as well as better performance than broadcasted direct seeding. This information is very important considering that broadcasted direct seedling has recently been practiced by farmers, especially in Southeast Sulawesi, because this practice is easy and inexpensive to apply.

\section{Conclusion}

Low-N application has lower rice blast incidence than recommended-N rate, high-N rate, and farmer's practice, both on jajar legowo 2:1 and broadcasted direct seeding. However, the recommended $\mathrm{N}$ application, even though has a higher disease incidence than low-N application, could tolerate yield loss due to rice blast by producing more productive tillers, number of grains per panicle, and reducing the number of unfilled grains. The jajar legowo 2:1 direct seeding gave lower disease incidence and severity to the rice blast than broadcasted direct seeding. The study suggested an appropriate recommended-N rate and jajar legowo 2:1 direct seeding (double row) was incorporated into the rice blast management strategies.

Acknowledgment. We wish to thank Suwarsono, the extension coordinator of Meluhu District, Konawe Regency, Southeast Sulawesi for allowing the authors to perform field trials along with the farmers under his assistance. The authors are also express gratitude to Abdul Rauf Sery for his technical assistance in the field experiment. This study was funded by DIPA BPTP Sulawesi Tenggara 2015.

\section{References}

1. D. Yuliani, and Y. E. Maryana, Integrasi Teknologi Pengendalian Penyakit Blas Pada Tanaman Padi Di Lahan Sub-Optimal, in Prosiding Seminar Nasional Lahan Suboptimal, September 22-27, Palembang (2014)

2. A. Sudir, Nasution, Santoso, and B. Nuryanto, Iptek Tanam. Pangan 9, 2 (2014)

3. J. Fernandez, and R. A. Wilson, Mol. Plant-Microbe Interact. 25, 10 (2012)

4. Y. Luo, D. O. TeBeest, P. S. Teng, and N. G. Fabellar, J. Biogeogr. 22, 4/5 (1995)

5. R. Bevitori, and R. Ghini, J. Rice Res. 3, 1 (2014)

6. X. Wang, S. Lee, J. Wang, J. Ma, T. Bianco, and Y. Jia, Current advances on genetic resistance to rice blast disease (Publisher: In Tech, Editor Wengui Yan, 2014)

7. T. Suganda, E. Yulia, F. Widiantini, and Hersanti, J. Agrik. 27, 3 (2016)

8. N. J. Talbot, H. R. K. McCafferty, M. Ma, K. Moore, and J. E. Hamer, Physiol. Mol. Plant Pathol. 50 (1997)

9. R. Galhano, and N. J. Talbot, Fungal Biol. Rev. 25, 1 (2011)

10. E. Kurschner, J. M. Boman, D. P. Garrity, M. M. Tamisin, D. Pabale, and B. A. Estrada, Plant Dis. 76, 4 (1992)

11. D. H. Long, F. N. Lee, and D. O. TeBeest, Plant Dis. 84, 4 (2000) 
12. S. Bregaglio et al., F. Crop. Res. 212 (2017)

13. I. B. Pangga, J. Hanan, and S. Eur. J. Plant Pathol. 135, 3 (2013)

14. A. Ghanbari-malidareh, World Acad. Sci. Eng. Technol. 5, 2 (2011)

15. J. Dusserre, H. Raveloson, R. Michellon, E. Gozé, S. Auzoux, and M. Sester, F. Crop. Res. 204 (2017)

16. C. Dordas, Agron. Sustain. Dev. 28 (2008)

17. A. K. Makarim, and Ikhwani, Teknik Ubinan: Pendugaan produktivitas padi menurut jarak tanam (Puslitbang Tanaman Pangan, Bogor, 2012)

18. Ikhwani, G. R. Pratiwi, E. Paturrohman, and A. K. Makarim, Iptek Tanam. Pangan 8, 2 (2013)

19. M. Farooq, K. H. M. Siddique, H. Rehman, T. Aziz, D. J. Lee, and A. Wahid, Soil Tillage Res 111, 2 (2011)

20. Sopialena, and P. J. Palupi, Biodiversitas, J. Biol. Divers. 18, 2 (2017)

21. R. Y. Deshpande, K. G. Hubbard, D. P. Coyne, J. R. Steadman, and A. M. Parkhurst, Agron. J. 87, 4 (1995)

22. Y.Y. Zhu et al., J. Phytopathology 95, 4 (2005)

23. C. Q. Torres and P. S. Teng, J. Crop Prot. 12, 4 (1993)

24. S. D. Koutroubas, D. Katsantonis, D. A. Ntanos, and E. Lupotto, J. Australas. Plant Pathol. 37 (2008)

25. C. J. Chuwa, R. B. Mabagala, and M. S. O. W. Reuben, Int. J. Sci. Res. 4,10 (2015)

26. Yulianto, Iptek Tanam. Pangan 12, 1 (2017) 